\section{IN-SILICO ALANINE SCANNING ANALYSIS ON THE CATALYTIC RESIDUES OF A NOVEL B- GLUCOSIDASE ASPERELLUM UC1 FROM TRICHODERMA}

Aimi Aliah Mohamad Yunusa, Roswanira Abdul Wahaba,b,*, Aina Hazimah Bahamana, Habeebat Adekilekun Oyewusib,c, Syariffah Nuratiqah Syed Yaacobb,c

aDepartment of Chemistry, Faculty of Science, Universiti Teknologi Malaysia, 81310 UTM Johor Bahru, Johor, Malaysia bEnzyme Technology and Green Synthesis Research Group, Department of Chemistry, Faculty of Science, Universiti Teknologi Malaysia, 81310 UTM Johor Bahru, Johor, Malaysia cDepartment of Bioscience, Faculty of Science, Universiti Teknologi Malaysia, 81310 UTM Johor Bahru, Johor, Malaysia
Article history

Received

8 July 2020

Received in revised form

7 February 2021

Accepted

30 March 2021

Published online

22 April 2021

*Corresponding author roswanira@kimia.fs.utm

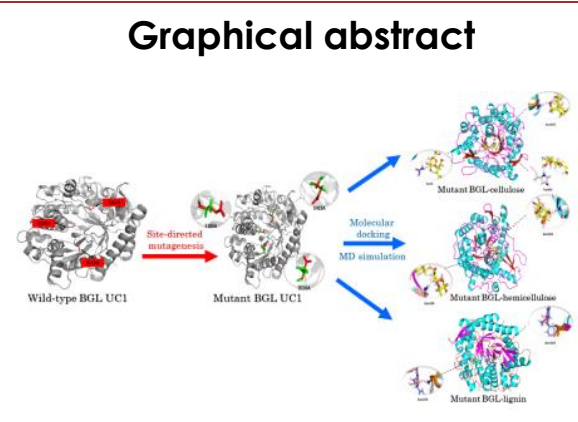

\begin{abstract}
Currently, the catalytic residue of the highly prolific fungal $\beta$-glucosidase (BGL) of Trichoderma asperellum UCl remains unvalidated. The study used the alanine scanning method to confirm the catalytic residues of the BGL as Glu165, Asp226, and Glu423. This method cancels out all intermolecular hydrogen bonds with substrates, lignin, hemicellulose, and cellulose. Results revealed an overall decline in the stability of the energy-minimized mutant enzymes' compared to the wildtype BGL. The mutant enzyme registered lower PROCHECK (91.0\%), ERRAT (93.09\%), and Verify-3D (98.92\%) values, in comparison to $90.2 \%, 92.09 \%, 98.06 \%$, in the wild-type BGL, respectively. The mutant BGL UCl-substrate complexes were less stable than the wild-type enzyme, in which the mutant exhibited higher binding energies for docked lignin $\left(-7.4 \% \mathrm{kcal} \mathrm{mol}^{-1}\right)$, cellulose $\left(-7.2 \mathrm{kcal} \mathrm{mol}^{-1}\right)$, and hemicellulose $\left(-7.2 \mathrm{kcal} \mathrm{mol}^{-1}\right)$. Binding energies of the wild-type $\mathrm{BGL}$ with the corresponding substrates were lower at $-7.9 \mathrm{kcal} \mathrm{mol-1},-8.1 \mathrm{kcal} \mathrm{mol}-1$, and -7.8

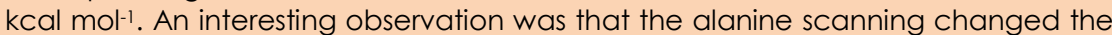
substrate preference order based on the calculated binding energies. The mutant $B G L$ bound preferentially to lignin>cellulose=hemicellulose, while the wild-type BGL was selective to cellulose>lignin>hemicellulose. Hence, the findings convey the high likelihood of Glu165, Asp 256, and Glu423 are the catalytic residues of the BGL of $T$. asperellum UC1.
\end{abstract}

Keywords: $\beta$-glucosidase from UCl, alanine scanning, catalytic triad, $\beta$ glucosidase, molecular docking, molecular dynamics 


\begin{abstract}
Abstrak
Kini, sisa pemangkin $\beta$-glukosidase kulat (BGL) Trichoderma asperellum UCl yang sangat produktif masih belum disahkan. Kajian ini menggunakan kaedah imbasan alanina untuk mengesahkan residu pemangkin BGL sebagai Glu165, Asp226, dan Glu423. Kaedah ini membatalkan semua ikatan hidrogen intermolekul dengan substrat, lignin, hemiselulosa, dan selulosa. Hasil kajian menunjukkan penurunan kecil kestabilan enzim mutan terminimum-tenaga berbanding BGL liar. Enzim mutan mencatatkan niai PROCHECK yang lebih rendah (91.0\%), ERRAT (93.09\%), dan Verifikasi-3D (98.92\%), berbanding BGL liar yang masing-masing ialah $90.2 \%$, 92.09\%, 98.06\%. Kompleks substrat mutan BGL UCl kurang stabil daripada enzim liar, di mana yang mutan menunjukkan tenaga pengikatan yang lebih tinggi untuk lignin berlabuh $\left(.47,4 \% \mathrm{kcal} \mathrm{mol}^{-1}\right)$, selulosa $\left(-7,2 \mathrm{kcal} \mathrm{mol}^{-1}\right)$, dan hemiselulosa $\left(-7.2 \mathrm{kcal} \mathrm{mol}^{-1}\right)$. Tenaga pengikat BGL liar dengan substrat masingmasing adalah lebih rendah pada $-7.9 \mathrm{kcal} \mathrm{mol}^{-1},-8.1 \mathrm{kcal} \mathrm{mol}-1$, dan $-7.8 \mathrm{kcal}$ $\mathrm{mol}^{-1}$. Pemerhatian yang menarik ialah pengimbasan alanin mengubah susunan pilihan substrat berdasarkan tenaga pengikat yang dikira. Mutan cenderung mengikat lignin $>$ selulosa $=$ hemiselulosa, sementara kepilihan BGL liar adalah terhadap selulosa> lignin> hemiselulosa.Oleh itu, hasil kajian ini menunjukkan kemungkinan besar Glu165, Asp 256, dan Glu423 adalah residu pemangkin BGL dari T. asperellum UC1.
\end{abstract}

Kata kunci: $\beta$-glucosidase daripada UC1, imbasan alanine, triad pemangkin, $\beta$ glucosidase, pengodekan molekul, dinamika molekul

(C) 2021 Penerbit UTM Press. All rights reserved

\subsection{INTRODUCTION}

Carbohydrate degrading enzymes secreted by the Trichoderma genus' fungi are favored due to their ability to secrete large quantities of the enzymes extracellularly [1]. Recently, Ezeilo et al. [2] isolated a novel $T$. asperellum UCl fungus (GenBank accession number MF774876) that secretes an array of synergistic carbohydrate hydrolyzing enzymes. The crude enzyme cocktail consisted of four endo- $\beta-1,4-$ xylanases and endoglucanases, and one exoglucanase and a $\beta$-glucosidase [1]. The enzymes are key bioremediation agents that recycle carbon from lignocellulosic biomass into the environment. Lignocellulose is the most abundant biopolymer on Earth, with cellulose, hemicellulose, and lignin being the major components [2-4]. However, this study focuses on the extracellular $\beta$-glucosidase (BGL) of $T$. asperellum UCl since it is among the commonplace enzymes produced by organisms [1].

BGL hydrolyzes $\beta$-glycosidic bonds of terminal non-reducing residue in $\beta-D$ - glucosides and oligosaccharides. This action liberates glucose or other sugars as products, which explains its valued role in cellulose saccharification and degradation [5]. The BGL of $T$. asperellum UCl has a higher enzymatic activity reportedly over other crude enzyme cocktails, in conjunction to better digests cellulosic components than $\beta$-glucosidases of $T$. reesei $[6,7]$. For this study to comprehend the catalytic workings of the BGL UC1, a resolved crystal structure of a comparable extracellular $\beta$ glucosidase called the ThBgl [8] was used as the enzyme template. The ThBgl falls under the $\beta$ retaining glycosyl $\mathrm{GH}$ l family (E.C. 3.2.1.21), in which protein architecture is made up of a single $(a / \beta)_{8}$ TIM barrel fold with two glutamate residues (Glu) as the catalytic residues that are placed at a certain distance to retain mechanism [8]. $\beta$-retaining glycosyl BGLs hydrolyze form glycosidic bonds in plants via a mechanism called deglycosylation. The mechanism is instigated by an attack on a water molecule by the general acid or base to discharge the glutamic acid (nucleophile) while the configuration of anomeric carbon is left unchanged [9]. Florindo et al. [10] deduced the catalytic residues of the BGL of ThBgl to be made up of nucleophilic Glu367 (E367) and Glul66 (E166). It is thought that the catalytic glutamate of BGL of $T$. asperellum UCl is at positions, Glu 165, and Glu423, alongside Asp226 [11]. However, this aspect is yet to be confirmed. Our earlier study only performed phylogenetic tree and sequence alignment studies to identify the species and characterized the biochemical- and catalytic behaviors of the BGL of $T$. asperellum UC1. We did not delve into the roles of the catalytic triad of the fungal enzyme. Although a crystal structure of another BGL is available, the catalytic residues of the BGL UCl remain an educated guess. Hence, there is still a lacking of affirmative investigation to identify the BGL UCl catalytic residues.

In this milieu, the method of alanine scanning comes in handy to validate active site residues. The technique has been regularly used to identify catalytic residues in various enzymes without disrupting their cores' folding [12]. In this study, the technique systematically substitutes putative catalytic residues with alanine, thereby nullifying any possible interactions between the side-chains of amino and the ligand(s) [13]. It was expected that 
the interaction of the mutant BGL-ligand complex $\left(\Delta G_{M}\right)$ becomes destabilized and gives a higher Gibbs free energy when compared to the wild-type $(\Delta G w)$. The more negative the value, the stronger the interaction between the side chain of the enzyme and ligand [14]. The method was useful to demonstrate the binding of human growth hormone $(\mathrm{hGH}$ ) to $\mathrm{hGH}-$ binding protein (hGHbp) [15], ligandbinding pocket for the human Vitamin $D$ receptor [16], and complete alanine scanning of the Esherichia coli RbsB ribose binding protein involved in chemoreceptor signaling [17] amongst many others.

Hence, the molecular modeling approach using in silico alanine scanning performed by using the GROMACS software can further expedite the clarification of the catalytic residues in BGL UCl. It can overcome the time-consuming, expensive, and laborious shortcomings in the conventional empirical validation studies to identify the catalytic residues. GROMACS allows the rapid comprehension of the structure-activity relationships between the substrate and an enzyme's binding site. The software can rapidly gauge changes in the mutant enzyme [18][19]. This technique highlights the salient contribution of in silico alanine scanning to expediently identify and affirm the catalytic residues of the BGL of $T$. asperellum $\mathrm{UCl}$ while complementing other empirical validation methods. It is hypothesized that the replacement of the putative catalytic residues in the BGL UCl invalidates the essential intermolecular hydrogen bonds that anchor the substrates into the active site. This, in turn, renders the general increase in binding energies of the $\beta$-glucosidase-substrate complex. Pertinently, this is the first study detailing the in silico attempt to identify the catalytic residues of the BGL BGL of $T$. asperellum $\mathrm{UCl}$.

Pertinently, the approach proposed here is feasible due to the availability of a similar threedimensional (3D) molecular model of the BGL of $T$. asperellum in the National Center for Biotechnology Information (NCBI) database. In this work, the 3D structure of the $\beta$-glucosidase $\mathrm{UCl}$ must first be constructed, followed by in silico substitution of Glu165, Asp226, and Glu423 into alanine, using the GROMACS package. Using AutoDock version 4.2.6, the enzyme's natural substrate was docked into the mutated catalytic site. Next, the study used molecular dynamics to estimate changes in binding energies before and post mutation.

\subsection{METHODOLOGY}

\subsection{Construction of the 3D Structure of $T$. asperellum UC1 by Homology Modeling}

The study first retrieved relevant data from the NCBI needed for protein Basic Local Alignment Search Tool (BLAST). This was necessary to identify homologous protein structures in the Protein Data
Bank [20]. The amino acid sequences of $\beta$ glucosidases were retrieved from GenPept database (ID: XP_018660766.2) in NCBI. Based on the highest percentage of sequence similarity of alignment (90.06\% similarity) for BGL (GenBank accession No. ARW78142.1) from another T. asperellum, isolated by another study, was selected as the structural template. Next, the target enzyme's homology modeling used the SWISS-MODEL comparative protein modeling server to construct the threedimensional (3D) structure of the BGL of Trichoderma asperellum $\mathrm{UCl}$. The generated three-dimensional (3D) structure of the fungal $\beta$-glucosidase of $T$. asperellum $\mathrm{UC} 1$ was saved as a PDB file.

\subsection{In Silico Site-directed Mutagenesis of BGL T. asperelum $\mathrm{UC} 1$}

Based on a previous study, three structurally conserved active site residues of the BGL were reportedly located at Glu165, Asp226, and Glu423 [11]. In this study, mutations of catalytic residues of BGL to alanine (Ala) were introduced by Pymol 2.3 to yield mutant residues Glu165Ala, Asp226Ala and Glu423Ala, respectively. The mutant $\beta$-glucosidase was analyzed on an on-line Site Directed Mutator server

(http://wwwcryst.bioc.cam.ac.uk/ sdm/sdm.php) to assess for any changes in protein stability after the triple mutations. The analysis was based on a specific structural environment of a known 3D structure of another BGL [21]. The sequence of a highly similar $B G L$ was obtained from a previously isolated $T$. asperellum (Genebank accession: ARW78142.1).

\subsection{Model Refinement by Energy Minimization}

Refinement of the generated model structure of the mutant BGL UCl was then completed by allowing a subroutine within the energy minimization to replace missing atoms of altered residues before minimizing the structure using the appropriate parameters. Energy minimization is mandatory for protein structures with mutations. The process refines the generated protein model and improves any significant errors from its native structure [22]. Molecular dynamics (MD) simulation to refine the $B G L$ of $T$. asperellum UCl model was carried out on a GROMACS 2018.6 using the Gromos96 53a7 forcefield. Here, energy minimization by the steepest descent and conjugate gradient methods was done [23]. This step is important to establish the native state of the $\mathrm{BGL} U \mathrm{Cl}$ protein structure and that it was truly at the global minimum [24]. The optimization process to obtain a better protein structure converges on achieving the model enzyme's highest possible absolute performance [25].

\subsection{Evaluation of Structural Validity}

The default parameters of ERRAT checked the constructed mutant BGL UCl model's reliability and 
quality to evaluate non-bonded interactions [26]. Next, VERIFY3D checked the sequences' compatibility to the structure $[27,28]$ using the SAVES server (http://servicesn.mbi.ucla.edu/SAVES/). The PROCHECK examined the stereochemical quality and authenticated the constructed 3D model of the BGL protein in the Ramachandran plot. This plot typically evaluates the correctness of backbone conformation based on phi/psi distribution and the presence of non-GLY residues at the disallowed regions in the model [28]

\subsection{Substrate Docking}

The ligands' 3D structures were constructed in ChemSketch [29], and docking simulations were performed on the Autodock version 4.2.6 and AutoTools 1.5.6.[20]. The binding region was defined by the Autogrid tool in Autodock as $\pm 1.000 \AA$ from $39.214 \AA, 39.185 \AA$, and $42.877 \AA$ coordinates with the sizes 22,16 , and 14 ( $x, y$ and $z$ positions, respectively). The docking analysis was performed in triplicate using the Autodock Vina for comparison purposes. For each substrate in this work, the best result was taken as the largest conformation cluster showing the lowest binding energy. The "pdbqt" file for each BGLsubstrate complex was converted into the pdb format and visualized using Pymol version 2.3[30].

\subsection{Simulation on Enzyme-ligand Complex}

BGL-substrate complexes were converted into the pdb format and visualized using Pymol version 2. MD simulation for refining each mutant BGL 3D model was done on the parallel version of GROMACS 5.1.2 using the Gromos96 $53 a 6$ force field. The mutant BGL protein was simulated in a cubic simulation box 10.0 x $10.0 \times 10.0 \mathrm{~nm}^{3}$ ) and solvated with $18000 \mathrm{SPC} / \mathrm{E}$ water molecules through the addition of counterions to neutralize the net charge of the enzymes [11,30]. A total of $7 \mathrm{Na}^{+}$were added for the $\mathrm{BGL}$, and the system was energy-minimized using the steepest descent algorithm. A maximum of 10,000 steps was used to ensure the protein-ligand complex's solvated system was free from steric clashes or incorrect geometry. The structures of ligand-bound mutated $\beta$ glucosidase proteins were evaluated. NVT and NPT were used to equilibrate the complete system by compiling for 50,000 steps (100 ps) at 300K at $1 \mathrm{~atm}$ [30]. The equilibrated structures were subjected to MD simulations for 100 ns in triplicate, with an integration time steps of 2 fs. Each output was obtained as a finished Xmgrace graph to analyze the simulation trajectory. The established step-by-step configuration in this work was founded on published protocols [31]. Analysis of the dynamic behavior and structural changes of the BGL protein model was performed by calculating the root mean square deviation (RMSD) and root mean square fluctuation (RMSF) at the end of the 100 ns production simulation [30]. RMSD quantifies the deviation from the minimized crystal structure, where each part of the protein has altered from the initial conformation over the production simulation time. RMSF exemplifies the deviation from the mean structure over a dynamic production simulation and demonstrates the protein's moving regions. In this work, the frame was stored at every 1.0 ps intervals during the simulation.

\subsection{RESULTS AND DISCUSSION}

\subsection{In Silico Site-directed Mutagenesis}

Previously, a BLAST search through the Protein Data Bank (PDB) using the target sequence as the query yielded the closest similarity to $B G L$ from a $T$. asperellum species (ARW78142.1) [30], BGL UC1 enzyme showed $90.04 \% \%$ of sequence identities to two other $T$. reesei fungi with PDB identification number of $3 \mathrm{AHY}$. The multiple sequence alignment of some BGL proteins was reported in our previous study, which showed their predicted conserved catalytic trial (Figure 1). The RMSD of the wild-type BGL model $\left(0.51^{\circ} \mathrm{A}\right)$ and the mutant enzyme (1.73 $\left.{ }^{\circ} \mathrm{A}\right)$ were both in the acceptance range (RMSD $<2$ $\left.{ }^{\circ} \mathrm{A}\right)$. In this study, the putative catalytic residues, namely the Glu165, Asp226, and Glu423, were mutated into alanine by the Pymol 2.3 program to give mutants Glu165Ala, Asp226Ala, and Glu423Ala, respectively. The sequence was subjected to homology modeling using the SWISS-MODEL web server to generate the 3D structures of the mutant BGL. Figures $1 \mathrm{a}$ and $1 \mathrm{~b}$ depict the SWISS-MODEL web server generated 3D structure of the $B G L U C l$ in cartoon. Literature has shown that $a>30 \%$ degree of sequence similarity between the target-template is acceptable for homology modeling studies [27, 32].

A naked-eye inspection of the wild-type and mutant BGL 3D structures yielded non-discernible structural differences. It appears that the generated 3-D structures of the mutant BGL protein preserved a similar fold as the wild-type enzyme (Figure 2). The study assumed that the backbone fold of the protein was retained after the substitution of the enzyme's catalytic residues with three alanine residues. There were subtle changes to the mutant BGL UC1 model structure, with slight rotations of side-chain torsions, revealing a minimum mixture of side-chain and mainchain shifts. 


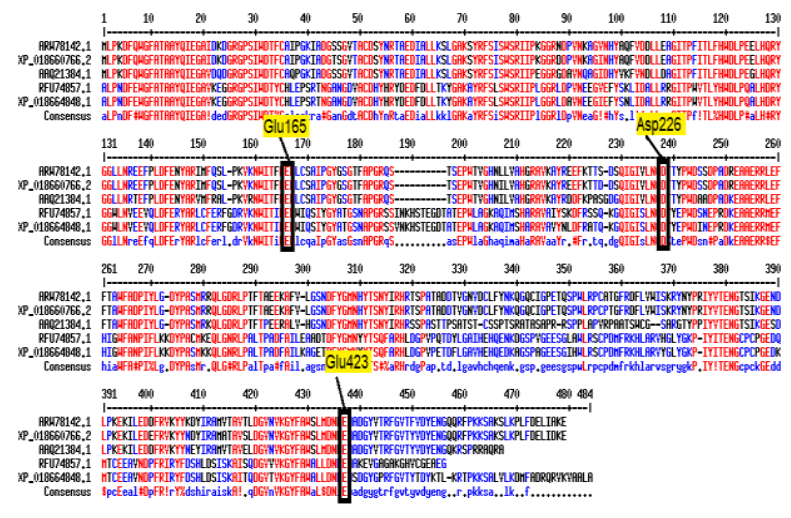

Figure 1 Multiple sequence alignment displaying the conserved catalytic triad of BGL UCl protein (Glul65Asp226-Glu423) (a)

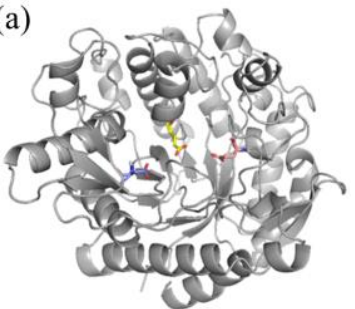

(b)

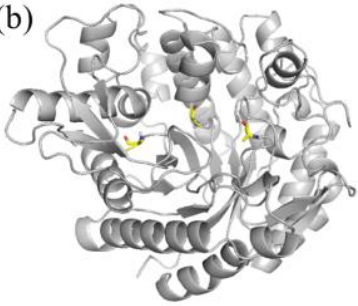

Figure 2 The SWISS-MODEL generated 3D structures of (a) wild-type BGL (b) mutant BGL UC1. Red, yellow, and green represent the a-helices, $\beta$-sheet, and loop of the enzyme

\subsection{Energy Minimization and Evaluation on the 3D Structure of Mutant BGL UC1}

All the models generated were energy minimized. Local strains within the generated 3D protein model for both wild-type and mutant $B G L$ models were eliminated by energy minimization using Gromos97 to procure stable structures for the subsequent substrate docking. This is because minor errors from localized strain(s) can exist in the original protein structure, such as atomic overlap or bad Van der Waals interaction [30]. Energy minimization of enzymes helped remove any local strain after the addition of hydrogens. Also, a broken hydrogen bond network in water would lead to large forces and structure distortion. Therefore, PROCHECK, ERRAT, and Verify-3D were used as indicators to verify and validate this data (Table 1).

In this study, the energy minimized mutant model of BGL UCl was docked with substrates, cellulose, hemicellulose, and lignin before molecular dynamic (MD) simulations. This step is important to observe interactions between substrates with the new catalytic residues mutant BGL model, namely Glu165Ala, Asp226Ala, and Glu423Ala. This study anticipated an increase in the binding energy between the substrates and the mutant $B G L$ catalytic residues. Crucially, a model structure showing higher binding energy signifies a negative or poorer interaction between the substrates and catalytic site. It also indicates the likelihood of catalytic failure. The energy minimized mutant $B G L$ $\mathrm{UCl}$ was subjected to several model evaluation tools to assess its quality (Table 1). In this study, evaluations were done on the local geometry (PROCHECK and ERRAT), while Verify3D gauged the mutant enzyme's local environment [27, 30,33].

Table 1 Summary of the validation result of wild-type and mutant BGL models before and after energy minimization

\begin{tabular}{lccccc}
\hline \multirow{2}{*}{$\begin{array}{l}\text { Model } \\
\text { Evaluation }\end{array}$} & $\begin{array}{c}\text { Normal } \\
\text { Score }\end{array}$ & \multicolumn{2}{c}{$\begin{array}{c}\text { Wild-type BGL } \\
\text { Tools }\end{array}$} & $\begin{array}{c}\text { Range } \\
\text { Range }\end{array}$ & \multicolumn{2}{c}{$\begin{array}{c}\text { Mutant BGL } \\
\text { (\%) }\end{array}$} \\
\hline Procheck & $>90$ & & After & Before & After \\
Verify3D & $>80$ & 90.0 & 90.5 & 89.9 & 90.2 \\
ERRAT & $>50$ & 93.65 & 98.85 & 98.04 & 98.04 \\
\hline
\end{tabular}

\subsubsection{PROCHECK}

PROCHECK examines the geometrical properties of protein molecules by analyzing the residue-byresidue geometry of the structure. A protein model's acceptable quality has over $>90 \%$ residues within the most favored regions [33]. The quality of the mutant BGL UCl was also evaluated based on the backbone conformation and overall stereochemical by observing the phi $(\Phi)$ and psi $(\Psi)$ torsion angles. The output of the analysis was demonstrated by Ramachandran plots (Figure 3). (a)

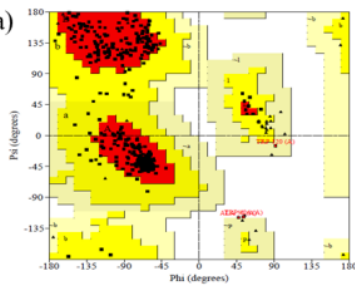

(c)

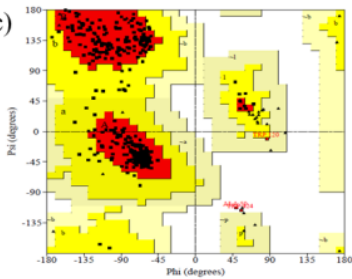

(b)

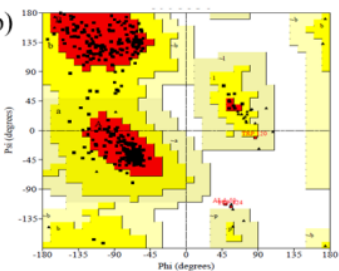

(d)

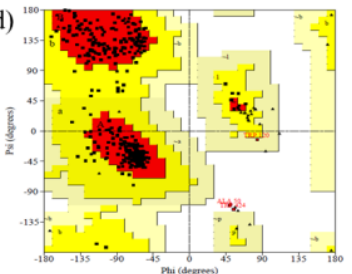

Figure 3 Plot calculation on the $3 \mathrm{D}$ models of $\mathrm{BGL} U \mathrm{UCl}$ computed by the PROCHECK program. The following is the comparison of Ramachandran's plot for (a) wild-type BGL UCl, (b) energy minimized wild-type BGL UCl model, (c) mutant BGL UCl and (d) energy minimized mutant BGL UCl model. The most favored regions $[A, B, L]$, the additional allowed regions $[a, b, l, p]$, the generously allowed regions $[\sim a, \sim b, \sim 1, \sim p]$ are colored in red, yellow, and pale yellow respectively. All non-glycine and proline residues are illustrated as a filled black square, and glycine (non-end) are indicated as filled black triangles; disallowed regions are colored in white 
Despite mutation of the catalytic residues, it appears that the 3D model of mutant BGL UCl retained good stereochemical quality as that of the wild-type enzyme. This was apparent in the Ramachandran plots where the plotted $(\Phi-\boldsymbol{\Psi})$ predicted model of the wild-type $B G L \cup C 1$, refined $B G L$, mutant $B G L$, and refined Mut-BGL (Figure 3) shared distribution of $99.5 \%$ amino acid residues in the allowed regions. About $0.5 \%$ of residues resided in a disallowed region. This meant that little has changed in terms of the quality of the protein structure post-mutation. For brevity, the most favored regions are labelled as $[A, B, L]$, the additional allowed regions as $[a, b, I, p]$, and the generously allowed regions are $[\sim a, \sim b, \sim 1, \sim p]$. Summary of the Ramachandran plot statistics for BGL of $T$. asperellum UCl by PROCHECK is presented in Table 2

Table 2 Summary of the Ramachandran plot statistics for BGL UCl as computed by PROCHECK

\begin{tabular}{|c|c|c|c|c|}
\hline \multirow[b]{2}{*}{$\begin{array}{l}\text { Stereochemical } \\
\text { parameter }\end{array}$} & \multicolumn{3}{|c|}{ Calculated Values (\%) } & \multirow[b]{2}{*}{$\begin{array}{c}\text { Refined } \\
\text { Mutant } \\
\text { BGL }\end{array}$} \\
\hline & $\begin{array}{l}\text { Wild- } \\
\text { type } \\
\text { BGL } \\
(\%)\end{array}$ & $\begin{array}{l}\text { Refined } \\
\text { Wild- } \\
\text { type } \\
\text { BGL }\end{array}$ & $\begin{array}{c}\text { Mutant } \\
\text { BGL }\end{array}$ & \\
\hline $\begin{array}{l}\text { Residue in most } \\
\text { favoured } \\
\text { regions }[A, B, L]\end{array}$ & 91.0 & $\%^{89.9}$ & $89.9 \%$ & $90.2 \%$ \\
\hline $\begin{array}{l}\text { Residue in the } \\
\text { additionally } \\
\text { allowed zones } \\
{[a, b, l, p]}\end{array}$ & 8.3 & $9.3 \%$ & $9.3 \%$ & $9.0 \%$ \\
\hline $\begin{array}{l}\text { Residue in the } \\
\text { generously } \\
\text { allowed regions } \\
{[\sim a, \sim \text { b. } \sim \text { l, } \sim \text { p] }}\end{array}$ & $0.3 \%$ & $0.3 \%$ & $0.3 \%$ & $0.3 \%$ \\
\hline $\begin{array}{l}\text { Residue in } \\
\text { disallowed } \\
\text { regions }\end{array}$ & $0.5 \%$ & $0.5 \%$ & $0.5 \%$ & $0.5 \%$ \\
\hline $\begin{array}{l}\text { Non-glycine } \\
\text { and non-proline } \\
\text { residues }\end{array}$ & $100.0 \%$ & $100.0 \%$ & $100.0 \%$ & $100.0 \%$ \\
\hline
\end{tabular}

\subsubsection{ERRAT}

The study also employed ERRAT to gauge the overall quality of the BGL UCl protein model. The web-server program verifies the $\mathrm{BGL}$ protein structures by the numbers of nonbounded contacts. The accepted valid range for an ERRAT score for a good protein model should be $>50 \%$ [30]. In this study, the ERRAT histogram depicted the correct regions and incorrect regions in grey and black, respectively (Figure 4). It is worth mentioning here that the two lines drawn indicated the confidence to reject regions that exceeded the $99 \%$ error value. Our data revealed that the BGL UCl protein model exhibited an overall good quality with corresponding values of $93.41 \%$, $92.09 \%, 91.43 \%$, and $92.09 \%$ for the wild-type and refined model, alongside the mutant- and the refined mutant $\beta$-glucosidase, respectively. The findings affirmed that the mutant fungal BGL UCl predicted 3D structure was good (>50\%) and reliable for the structural analysis.

(a)

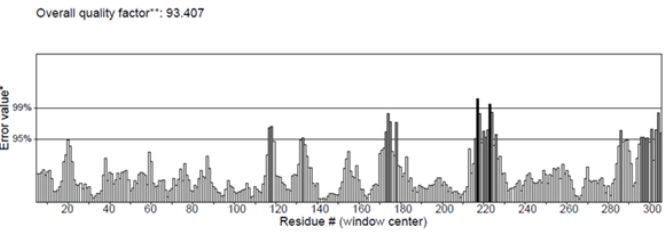

(b)

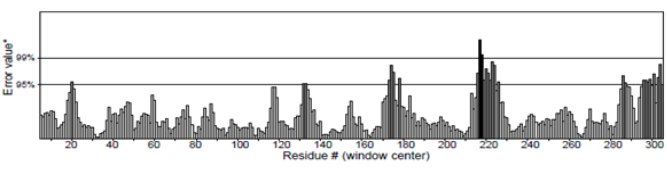

(c)

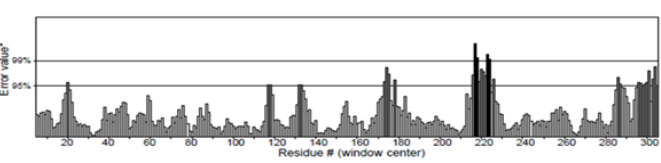

(d)

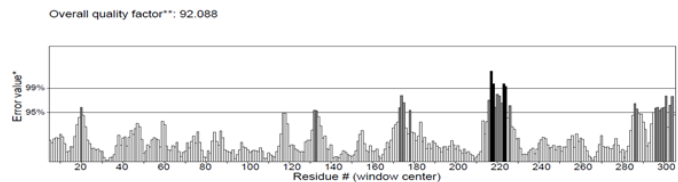

Figure 4 Overall quality of the models evaluated by the ERRAT for (a) non-refined BGL, (b) BGL after refinement, (c) mutated BGL, and (d) refined Mut-BGL. Black bars represent the poorly modeled regions, grey bars depict the error region, while white bars indicate the region with a lower error rate for protein folding

\subsubsection{VERIFY-3D}

Data calculated using Verify3D are useful in establishing an atomic model's compatibility with its own amino acid sequence. This is done by assigning a structural class based on its location and environment. Kuriata et al. [34] deemed that a satisfactory Verify3D score should be $>80 \%$. In this study, the data of Verify3D revealed the wild-type BGL UCl has a score of $98.92 \%$ while refined-, mutant- and the refined mutant BGL UCl showed a marginally reduced common score of $98.06 \%$ (Figure $5)$. The high scores for Verify3D seen here indicated the tested protein models achieved good side chain environments. In all, the integrated data of PROCHECK, ERRAT, and Verify3D for the mutant BGL UClexceeded the minimum cut-off score for a good 3-D structure. This conveyed that the mutant BGL UC1 maintained overall structural stability close to its wildtype counterpart. 
(a)

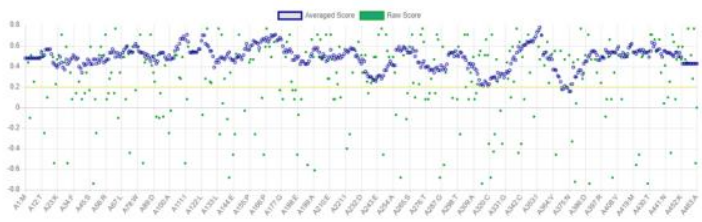

(b)

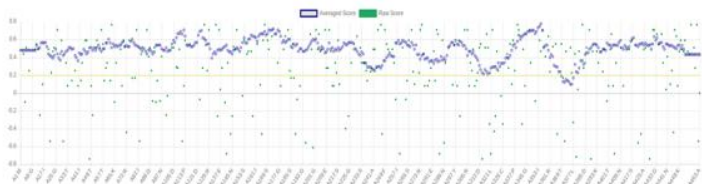

(c)

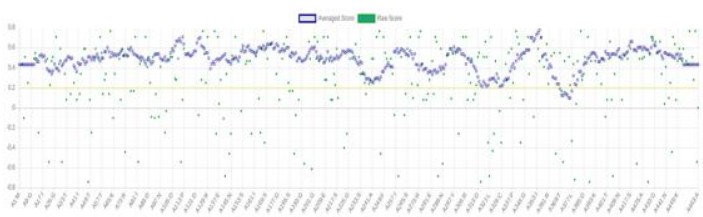

(d)

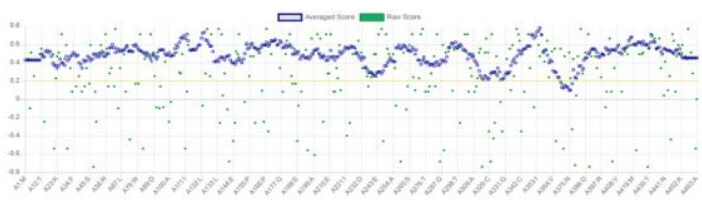

Figure 5 Results of Verify3D for (a) wild-type-, (b) refined-, (c) mutant-and (d) refined mutant BGL UCl with the score corresponding to $98.92 \%, 98.06 \%, 98.06 \%$ and $98.06 \%$, respectively.

\subsection{The 3D Modeling of Refined Mutant BGL UC1 Structure}

Comparison of $3 D$ poses of refined $B G L U C l$ and mutant $B G L U C l$ is presented in Figure 6. There were subtle differences in the protein's conformation in the proximity of the mutation sites, obtained from the superimposed proteins of the wild-type and mutant BGL UCl (Figure 2 (a)). Protein side chains at positions 165,226 , and 423 of wild-type BGL UCl appeared longer and more kinked. These changes were consistent with the presence of larger side chains of three- and two carbon carboxylic acids of glutamic acid (residue 165) and aspartic acid (residues 226 and 423), respectively [35]. Whereas residues E165A, D226A, and D423A of MUt-BGL UCl adopted a more compact structure that corresponded well with the smaller methyl $(-\mathrm{CH} 3)$ side chain of alanine.

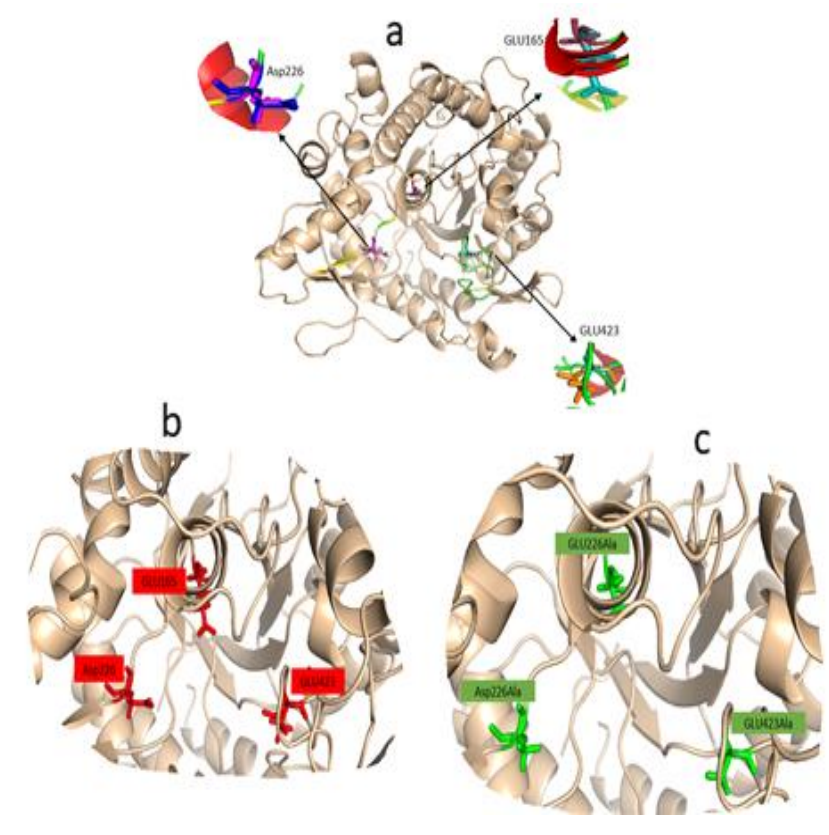

Figure 6 Comparison of wild-type BGL UC1 protein structure with its mutant. (a) The superimposed 3D structure of wildtype BGL UCl protein (red) with mutant BGL UCl (green) and locations of mutated residues of E165A, E423A on the front side view, while D226A is shown as the backside view. (b) The individual tertiary structure of wild-type BGL UC1 before mutation and (c) the mutant BGL UCl after mutation to Ala

To further examine the crucial key catalytic residues of mutant BGL UCl for protein-chemical interactions, the in silico site-directed mutagenesis showing mutations on the catalytic amino acid residues was used to create substitutions, followed by docking simulations [36]. Herein, the conserved residues 165,265 , and 423 of the mutant $B G L U C 1$ were mutated from Glu and Asp to Ala. The introduction of non-polar residues will hypothetically nullify hydrogen bonds forming between the docked substrates and the catalytic residues of $\mathrm{BGL} \mathrm{UCl}$. In this investigation, the results of the on-line Site Directed Mutator data showed that residues El65 $(\Delta \Delta \mathrm{G}=), \mathrm{D} 265(\Delta \Delta \mathrm{G}=)$ ) and $\mathrm{E} 423(\Delta \Delta \mathrm{G}=)$ ) yield values of $\Delta \Delta G$ corresponding to $-0.51 \mathrm{kcal} \mathrm{mol}-1,-0.14$ $\mathrm{kcal}$ mol-1 and $-1.13 \mathrm{kcal} \mathrm{mol}-1$. The predicted data was that the resultant alanine scanning mutation on BGL UCl had destabilized the 3D structure, proven by the decrease in protein stability post mutation. A positive and negative sign corresponds to destabilizing and stabilizing mutations predicted to decrease and increase the binding affinity of an enzyme-substrate complex. Literature has shown that destabilizing mutations at catalytic residues typically result in gains in binding energies of proteins or enzyme-protein complexes [37]. 


\subsection{Molecular Docking of Mutant BGL UC1 with Cellulose, Hemicellulose, and Lignin}

This study's subsequent investigation involved molecular docking of the natural substrates, cellulose, hemicellulose, and lignin into the refined structures of the wild-type- and mutant BGL UC1. This investigation compared the interaction between the enzyme and the three ligands using the AutoDock version 4.2.6 and AutoTools 1.5.6, followed by AutoGrid tools. Considering that mutant BGL UCl has three alanine residues replacing the putative catalytic residues in BGL UC1 (Glu165, Asp226, and Glu423), hydrogen bonds between the carbonyl oxygen atom of the substrates were not expected to occur. Another scenario that may transpire was forming another type of hydrophobic interaction (in lieu of alanine's neutral nature) with a 'neighboring' amino acid. This scenario is possible for the mutant BGL UCl as residues in its catalytic pocket are tightlypacked as any other enzymes. Close-ranging residues are bound to be attracted to one another, as 'likes attract likes.' Furthermore, the complexity of a protein structure is determined by the sequence of amino acids. Meanwhile, the available group side chains' chemical nature and the polar and nonpolar side chains, alongside the twisting and conformations of proteins, are caused by hydrophobic and hydrophilic interactions. Hence, alanine's hydrophobicity enables the residue to be 'wedged' into tight loops or chains.

A previous study has shown that the wild-type BGL UCl docked with cellulose $\left(-8.1 \mathrm{kcal} \mathrm{mol}^{-1}\right)$ recorded the most favorable binding energy followed by lignin $\left(-7.9 \mathrm{kcal} \mathrm{mol}^{-1}\right)$ and hemicellulose $\left(-7.5 \mathrm{kcal} \mathrm{mol}^{-1}\right)$. As anticipated, mutation with alanine yields the BGL UCl-substrate complex showing increased binding energies to the substrate lignin $\left(-7.4 \mathrm{kcal} \mathrm{mol}^{-1}\right)$, cellulose $\left(-7.2 \mathrm{kcal} \mathrm{mol}^{-1}\right)$, and hemicellulose $(-7.2$

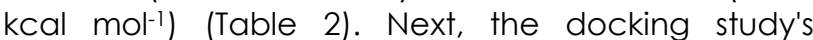
binding energy was used to calculate the equilibrium dissociation constant (Ki) as described by Manas et al. [38]. Low binding energy is related to a low Ki value that signifies high binding affinity, and this can measure substrate-binding strength with the enzyme. From the docking analysis of the mutant GBL model, lignin exhibited the lowest Ki value $\left(2.8239 \times 10^{-6}\right)$, followed by cellulose and hemicellulose (3.9887 X 106 6. Conversely, the Ki was constant for cellulose and hemicellulose (Table 3). The data proved that lignin was bound tightly to BGL UCl. On the other hand, the wild-type of $B G L$ showed that cellulose displayed the lowest $\mathrm{Ki}$ value $\left(8.432 \times 10^{-7}\right)$, followed by hemicellulose $\left(1.415 \times 10^{-6}\right)$ and cellulose $\left(1.191 \times 10^{-}\right.$ 6) (Table 3). The results seen here indicated the poor interaction between the mutant BGL UCl-substrate complex after the triple substitutions of Glu165, Asp265, and Glu423 with alanine. The data was also affirmative of the residues' important role in the hydrolysis of the three aforesaid natural substrates of BGL. Interestingly, the mutation led to a change in the substrate-binding preference order of the mutant
BGL UCl. The mutant enzyme preferred lignin over hemicellulose and cellulose. Conversely, the wildtype BGL favorably hydrolyzed cellulose, followed by lignin and hemicellulose [11]. Thus, our in silico study's outcome supported the catalytic role of residues Glu165, Asp265, and Glu423 in BGL UC1 to hydrolyze cellulose, lignin, and hemicellulose [1]. Thus, the increased binding energies strongly indicated that replacing the catalytic residues with alanine has marked adverse repercussions on hydrolytic activity and substrate specificity of the mutant of BGL UCl.

The best interaction poses for the protein-ligand complex of mutant BGL UC1 model are illustrated in Figure 7. The lower binding energy recorded for lignin indicated a stronger binding in the protein-ligand complex interaction, as the carboxylate group of BGL UCl formed hydrogen bonds to Asn224 and Trp424 at distances of $2.3 \AA$ and $3.0 \AA(<3.0 \AA)$ (Figure $6 c$ ), respectively. Mutation to alanine led to weaker hydrogen bond interactions in mutant BGL UC1 model with cellulose through residues Asn 164

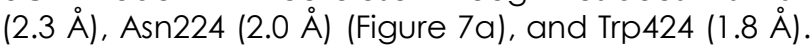
The same was also observed for hemicellulose through Asn164 (2.1 $\AA$ ) and Asn224 (1.6 ̊) (Figure 7b). Intermolecular distances of less than $3 \AA$ are universally accepted, as which hydrogen bonds are formed $[39,40]$. Pertinently, the appreciable increase in binding energies for all mutant BGL UCl-substrate complexes, alongside the reduced number of hydrogen bonds in the enzyme-hemicellulose and enzyme-lignin complexes, were clear indications of their reduced stability of interactions. The findings thus hypothetically validated the reduced ability of the mutant BGL UCl to hydrolyze all three substrates while arguably, affirming the catalytic role of Glu165, Asp226, and Glu423.

Table 3 Comparison of the minimum binding energies in $\mathrm{kcal} / \mathrm{mol}$, as estimated for the wild-type- and mutant BGL $\mathrm{UCl}$ as calculated by AutoDock.

\begin{tabular}{|c|c|c|c|}
\hline \multirow{2}{*}{ Ligand } & \multicolumn{2}{|c|}{$\begin{array}{l}\text { Binding Energy } \\
\text { (kcal/mol) }\end{array}$} & \multirow{2}{*}{ Residues } \\
\hline & $\begin{array}{l}\text { Wild- } \\
\text { type }\end{array}$ & Mutant & \\
\hline Cellulose & -8.1 & -7.2 & $\begin{array}{l}\text { Asn224 - Asn164 - } \\
\text { Trp424 }\end{array}$ \\
\hline Hemicellulose & -7.8 & -7.2 & Asn 164 - Asn224 \\
\hline Lignin & -7.9 & -7.4 & Asn224 - Trp424 \\
\hline
\end{tabular}




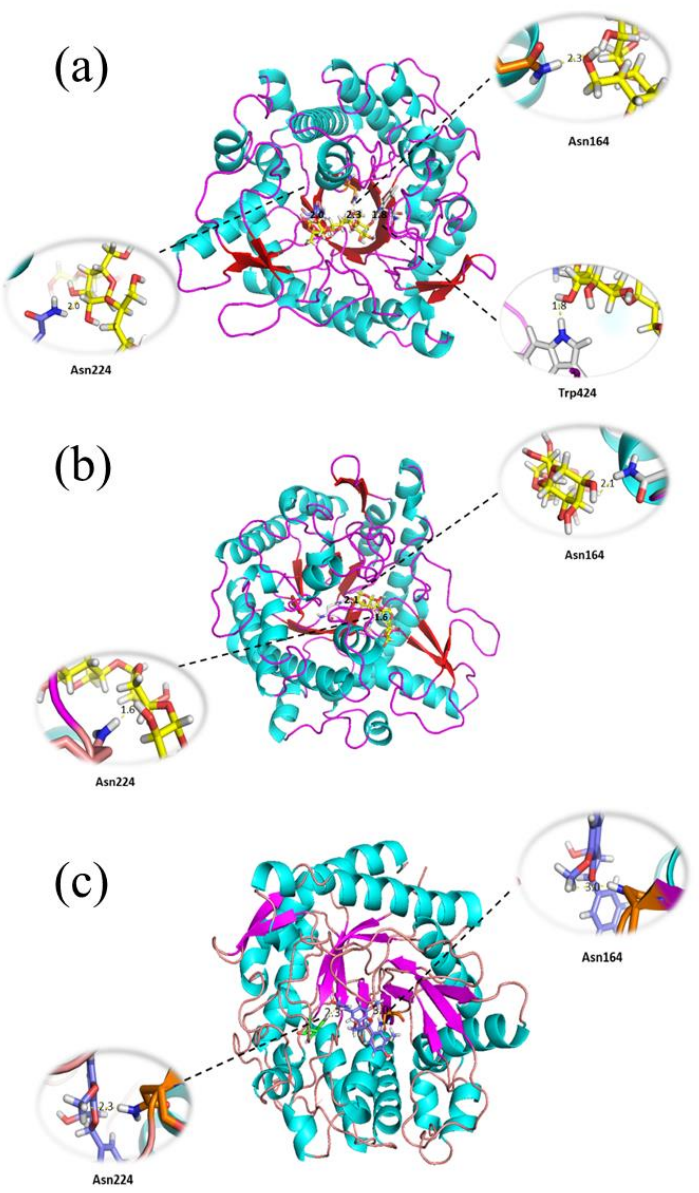

Figure 7 The best interaction poses for the protein-ligand complex by molecular docking; (a) mutant BGL-cellulose, (b) mutant BGL-hemicellulose, and (c) mutant BGL UCllignin complexes. $\quad-->$ (a) mutant BGL-cellulose formed hydrogen bond at Asn224, Asn 164, and Trp424, (b) mutant BGL interact with hemicellulose by hydrogen bonding at Asn 164 and Asn224 residue, and (c) mutant BGL UC1-lignin complexes formed the hydrogen bond at Asn224 and Trp424. The hydrogen bond distances are illustrated as yellow dashed lines.

\subsection{Simulations of the BGL UC1-ligand Complex}

Protein-ligand interactions are a prerequisite to visualizing the structural and dynamic characteristics of the mutant BGL UCl model. In this study, the initial protein-ligand molecular interactions were docked by AutoDock 4.2 using the classical Lamarckian genetic algorithm (LGA) as energy optimization algorithms. The best conformations of each docking algorithm were then subjected to molecular dynamic (MD) simulations to analyze the molecular mechanisms of protein-ligand interactions further. Here, we analyzed the binding energy between the protein receptors and ligands, hydrogen bonds' interactions in the docking region, and the structural changes when the wild-type- and mutant BGL UCl model interact with all three substrates. In this study, MD simulation was performed by looking at the total root mean square deviation (RMSD) and total root mean square fluctuation (RMSF) of the $\mathrm{Ca}$ backbone-backbone. We assessed the RMSD to study the residue behavior of the protein during the simulations. In general, a residue's RMSD value represents the local flexibility of a protein. It reflects the mobility of an atom during the MD simulation trajectory. Therefore, a higher residue RMSD value indicates a higher mobility. Conversely, a lower residue RMSD value indicates lower mobility. A relatively lower RMSD value indicates the complex structures' high stability and vice versa [41, 42]. Therefore, a complex's stability is affected by the binding affinity between a ligand and its target molecule.

The MD simulations of BGL-cellulose complexes were run in a $10 \AA$ cubic box containing water molecules at $300 \mathrm{~K}$, and the spc216 template was applied to solvate the protein [11]. All MD simulations were carried out by the GROMACS 5.1.2 package using the Gromas96 $53 a 6$ force field. The BGL UC1substrate complexes' trajectories were appreciably stable for the most part of the 100 ns production simulation run. The trajectory stability was checked and corroborated by the RMSD analysis (Figure 8) as the function of time for the mutant BGL UC1-substrate complexes. The RMSD values for all mutant BGL complexes increased in the first $10 \mathrm{~ns}$ and stabilized for most of the simulation (Figure $8 \mathrm{a}$ ). RMSD value of the mutant $\mathrm{BGL} U \mathrm{UCl-cellulose}$ revealed that the system first reached equilibrium at $30 \mathrm{~ns}(2.4 \AA)$ and fluctuated closely between $1.2 \AA$ to $2.5 \AA$. Notably, $M D$ simulation for mutant BGL UC 1-lignin equilibrated soon after 42 ns $(2.5 \AA)$, and its corresponding RMSD value fluctuated between $1.2 \AA$ to $2.8 \AA$. The complex incrementally deviated (RMSD $\sim 2.5 \AA$ ) and fluctuated again to 2.8 at 98 ns (Figure $8 \mathrm{a}$ ). Conversely, the mutant $\beta$-glucosidase-hemicellulose complex RMSD value fluctuated between $1.1 \AA$ to 2.5 $\AA$ while equilibrated at 72 ns $(2.4 \AA)$.

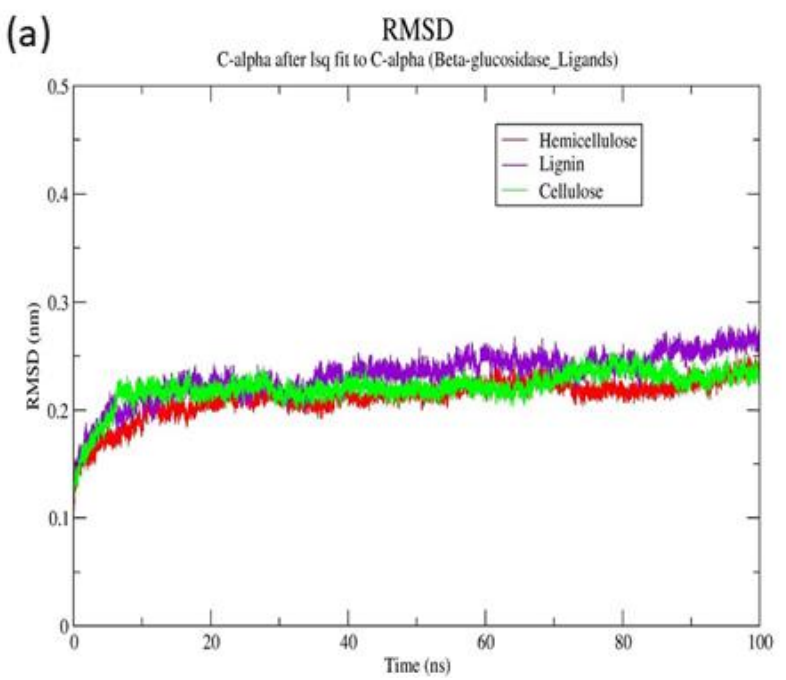


(b)

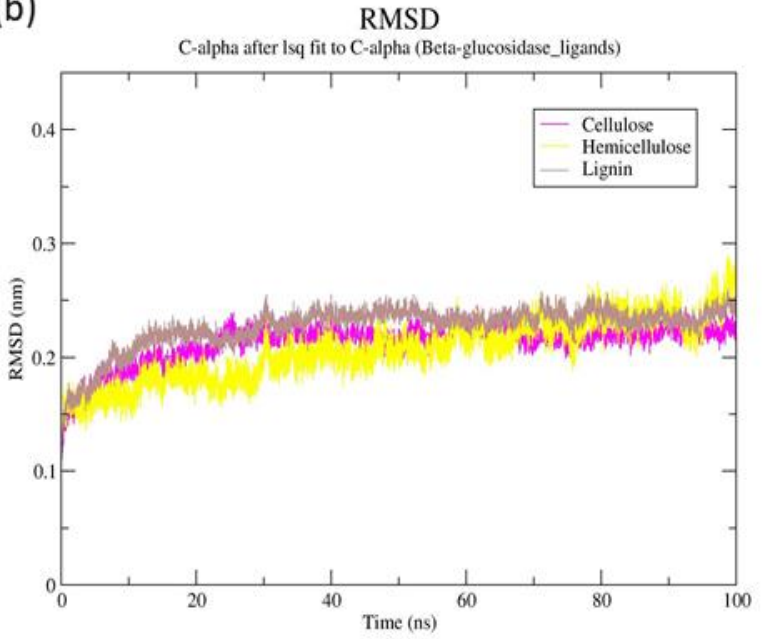

Figure 8 Averaged RMSD plots were computed for $100 \mathrm{~ns}$ at constant temperature and volume for (a) mutant BGLcellulose, mutant BGL-hemicellulose, and mutant BGL-lignin complexes and (b). wild-type BGL-cellulose, wild-type BGLhemicellulose, and wild-type BGL-lignin complexes

Conclusively, the afore MD data reiterated the lower binding ability of the mutant $B G L U C l$ to interact with the natural substrates of $B G L U C l$, namely, cellulose, hemicellulose, and lignin. The observation was consistent with the inability of the triple alanine substitutes to bind them strongly. Nonetheless, the $\beta$-glucosidase-cellulose complex appeared to be more stable than the two other complexes. Despite the mutation, the trend was seen to correlate excellently with an earlier study on the wild-type BGL UCl by Bahaman et al. [11]. RMSD of the BGL-cellulose complex showed the system reached equilibrium at $25 \mathrm{~ns}(2.2 \AA)$ and fluctuated narrowly within the range $1.0-2.2 \AA$ (Figure $8 \mathrm{~b}$ ). In comparison, the average RMSD value for $B G L$ hemicellulose complex ranged between $1.2-2.8 \AA$. This was followed by an increase in deviation (RMSD $\sim 2.5 \AA$ ) and fluctuated to $2.8 \AA$ at $97 \mathrm{~ns}$ (Figure 8b). For the RMSD of the BGL-lignin complex, the system reached equilibrium at $30 \mathrm{~ns}(2.4 \AA)$ within a range of 1.5 - $2.4 \AA$ (Figure 8b). Remarkably, the results showed that their BGL-cellulose complex was the most stable structure. Their results also agreed with observations from the docking study with the substrate cellulose $\left(-8.1 \mathrm{kcal} \mathrm{mol}^{-1}\right)$ compared to lignin $\left(-7.9 \mathrm{kcal} \mathrm{mol}^{-1}\right)$ and cellulose complex $\left(-7.8 \mathrm{kcal} \mathrm{mol}^{-1}\right)$. While the mutant BGL UCI MD simulation results refuted the earlier substrate docking data showing lignin being the preferred substrate, the study by Bahaman et al. [11] showed that the wild-type BGL UCl binding energies in complexed with lignin, cellulose and hemicellulose were $-7.4 \mathrm{kcal} \mathrm{mol}^{-1},-7.2 \mathrm{kcal} \mathrm{mol}^{-1}$ and $-7.2 \mathrm{kcal} \mathrm{mol}^{-1}$, respectively.

Confirming an early study by Cheng [ 40], a RMSD value that fluctuates $>3.0 \AA$ is acceptable for stable protein structure [43]. However, the MD simulations results for mutant $B G L U C 1$ negated the wild-type
BGL UCl substrate docking data which showed lignin as the preferred substrate. Again, our results proved that alanine scanning on the $\mathrm{BGL} \mathrm{UCl}$ catalytic triad did alter the enzyme's specificity and catalytic properties, as stated by [44]. Nonetheless, such a change requires further empirical study since this study focused on the consequence of the in silico mutation on BGL UC1.

To identify the flexible residues in the mutant $B G L$ UCl-substrate complexes, root mean square fluctuations (RMSF) were calculated from the MD trajectories. The residue number is shown in the abscissa axis, and the RMSF for the Ca of each residue is the inordinate axis. It is worth mentioning that the threshold value of RMSF at $>0.5 \AA$ represents a significant change in structural movements that correspond with enzyme stability [45]. As can be seen, the RMSF plots appeared stable for most of the simulation trajectory, fluctuating between $0.5 \AA$ to 3.1 $\AA$ for all mutant BGL UC1-substrate complexes (Figure 9). The highest RMSF peak for the mutant BGL UClcellulose complex was sited at residue 315 at $3.1 \AA$. Several other fluctuations were also identified at residues $23,50,218$, and 440 , with values ranging between $2.4 \AA$ to $3.0 \AA$. Comparingly, the wild-type BGL UCl-cellulose highest peak was recorded differently compared to its mutant-cellulose complex for residue 48 at $3.0 \AA$ [11]. This was an apparent distinction in the mutant BGL UCl protein's flexibility compared to the wild-type, despite their close structural similarity seen in earlier PROCHECK, ERRAT, and Verify3D assessments.

As shown in Figure 8, a small fluctuation is incidental of the a-helix region's low flexibility compared to its average position, which implied a rigid secondary structure conformation. RMSF value of wild-type BGL UCl appeared stable for most of the simulation trajectory, fluctuating only between 0.5-3.1 ̊. Comparingly, mutant BGL UCl complexes recorded the same fluctuation average. However, the wild-type BGL UCl-cellulose complex's highest peak was recorded differently compared to its mutant-cellulose complex for residue 48 at $3.0 \AA$. This was an apparent distinction in the flexibility of the mutant BGL UCl protein compared to the wild-type. The protein fluctuation was then related to the catalytic residue of mutant $\mathrm{BGL} U \mathrm{CCl}$ to recognize and interact with all three substrates as mutation took place. This can further influence the complexes' behavior and catalytic activity, resulting in the enzyme's poor ability to bind all three substrates.

Hence, it can be construed that the observed disparity in protein fluctuation was related to the mutant BGL UCl catalytic residues' ability to recognize and interact with the substrates (cellulose, hemicellulose, and lignin). This was consistent with the markedly poorer ability of the enzyme to bind the substrates. Finally, this study's findings collectively affirmed the crucial role of Glu165, Asp26, and Glu423 as the catalytic residues of BGL secreted by the fungus $T$. asperellum UCl. 


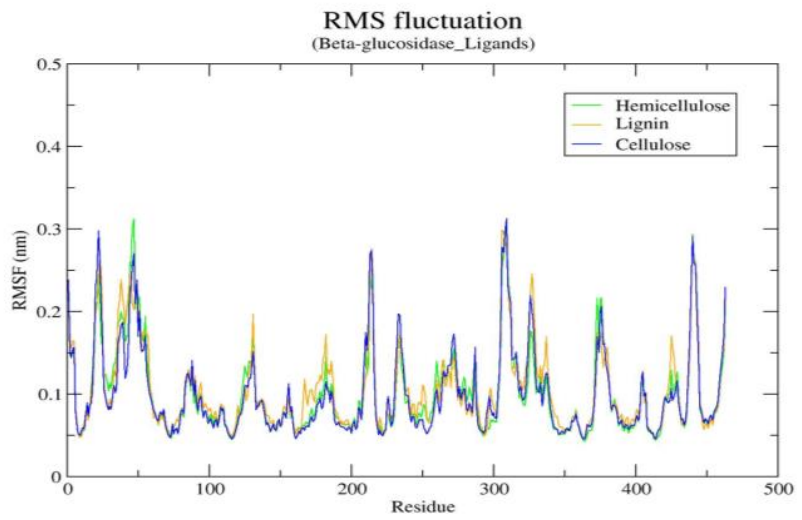

Figure 9 The RMSF of the Ca atoms in the mutant BGLcellulose, -hemicellulose, and -lignin complexes showing stable interactions

\subsection{CONCLUSION}

Based on this research, this study successfully constructed a 3D structure of mutant BGL UCl using the SWISS-MODEL data extracted from NCBI based on the BGL (ARW78142.1) amino acid sequence. This allowed the subsequent in silico site-directed mutation on the catalytic triad (Glu 165, Asp226, and Glu423) with the neutral and chargeless amino acid, alanine. The in-silico docking of substrates, cellulose, lignin, and hemicellulose (ligand) into the wild-type and mutant BGL UCl active sites corroborated the crucial catalytic role of Glu165, Asp226, and Glu423 in the enzyme. This was proven after comparing the binding energies of the wild-type BGL UCl with its mutant counterpart. A notable increase in the enzyme-substrates complexes' binding energies proved the diminished catalytic role of the active site of mutant BGL UCl to bond the substrates tightly for further hydrolysis. Thus, we demonstrated that the alanine scanning could assert that the Glu165, Asp226, and Glu423 were pertinent in hydrolyzing the substrates.

\section{Acknowledgment}

The authors would like to express their gratitude to the Department of Chemistry, Faculty of Science, Universiti Teknologi Malaysia for their facilities. This work was supported by the High Impact Research Grant (grant number Q.J130000.2454.08G45) awarded by Universiti Teknologi Malaysia.

\section{References}

[1] Ezeilo, U. R., Lee, C. T., Huyop, F., Zakaria, I. I. and Wahab, R. A. 2019. Raw Oil Palm Frond Leaves as Cost-Effective Substrate for Cellulase and Xylanase Productions by Trichoderma Asperellum UCl under Solid-state
Fermentation. Journal of Environmental Management. 243206-217.

DOI:https://doi.org/10.1016/j.jenvman.2019.04.113.

[2] Ezeilo, U. R., Wahab, R. A. and Mahat, N. A. 2020 Optimization Studies on Cellulase and Xylanase Production by Rhizopus Oryzae UC2 using Raw Oil Palm Frond Leaves as Substrate under Solid State Fermentation. Renewable Energy. 1561301-1312. DOI:https://doi.org/10.1016/j.renene.2019.11.149.

[3] Elias, N., Chandren, S., Razak, F. I. A., Jamalis, J., Widodo, N. and Wahab, R. A. 2018. Characterization, Optimization and Stability Studies on Candida Rugosa Lipase Supported on Nanocellulose Reinforced Chitosan Prepared from Oil Palm Biomass. International Journal of Biological Macromolecules. 114306-316. DOl:https://doi.org/10.1016/j.ijbiomac.2018.03.095.

[4] Elias, N., Wahab, R. A., Chandren, S., Razak, F. I. A. and Jamalis, J. 2019. Effect of Operative Variables and Kinetic Study of Butyl Butyrate Synthesis by Candida Rugosa Lipase Activated by Chitosan-reinforced Nanocellulose Derived from Raw Oil Palm Leaves. Enzyme and Microbial Technology. DOI:https://doi.org/10.1016/j.enzmictec.2019.109367.

[5] Tiwari, P., Misra, B. N. and Sangwan, N. S. 2013. $\beta-$ Glucosidases from the Fungus Trichoderma: An Efficient Cellulase Machinery in Biotechnological Applications. BioMed Research International. 2013203735. DOl:https://doi.org/10.1155/2013/203735.

[6] Asad, S. A., Tabassum, A., Hameed, A., Afzal, A., Khan, S. A., Ahmed, R. and Shahzad, M. 2015. Determination of Lytic Enzyme Activities of Indigenous Trichoderma Isolates from Pakistan. Brazilian Journal of Microbiology. 46(4): 1053-1064. DOI:https://doi.org/10.1590/S1517838246420140787.

[7] Bech, L., Busk, P. K. and Lange, L. 2015. Cell Wall Degrading Enzymes in Trichoderma Asperellum Grown on Wheat Bran. Fungal Genom Biol. 4116. DOl:https://doi.org/10.4172/2165-8056.1000116.

[8] Santos, C. A., Zanphorlin, L. M., Crucello, A., Tonoli, C. C. C., Ruller, R., Horta, M. A. C., Murakami, M. T. and de Souza, A. P. 2016. Crystal Structure and Biochemical Characterization of the Recombinant ThBgl, a GHI $\beta$ Glucosidase Overexpressed in Trichoderma harzianum under Biomass Degradation Conditions. Biotechnology for Biofuels. 9(1): 71. DOl:https://doi.org/10.1186/s13068-0160487-0.

[9] McIntosh, Lawrence P., Greg Hand, Philip E. Johnson, Manish D. Joshi, Michael Körner, Leigh A. Plesniak, Lothar Ziser, and Warren W. Wakarchuk. "i Withers, S. G. 1996. The pKa of the General Acid/Base Carboxyl Group of a Glycosidase Cycles during Catalysis: A13c-NMR Study of Bacillus Circulans Xylanase. Biochemistry. 35(31): 99589966. DOl:https://doi.org/10.1021/bi9613234.

[10] Florindo, R. N., Souza, V. P., Mutti, H. S., Camilo, C. Manzine, L. R., Marana, S. R., Polikarpov, I. and Nascimento, A. S. 2018. Structural Insights into BGlucosidase Transglycosylation based on Biochemical, Structural and Computational Analysis of Two GHI Enzymes from Trichoderma harzianum. New Biotechnology. DOl:https://doi.org/10.1016/j.nbt.2017.08.012

[11] Bahaman, A. H., Wahab, R. A., Abdul Hamid, A. A., Abd Halim, K. B. and Kaya, Y. 2020. Molecular Docking and Molecular Dynamics Simulations Studies on $\beta$-glucosidase and Xylanase Trichoderma asperellum to Predict Degradation Order of Cellulosic Components in Oil Palm Leaves for Nanocellulose Preparation. Journal of Biomolecular Structure and Dynamics. 1-14. DOI:https://doi.org/10.1080/07391102.2020.1751713.

[12] Fellinger, K., Leonhardt, H. and Spada, F. 2008. A Mutagenesis Strategy Combining Systematic Alanine Scanning with Larger Mutations to Study Protein Interactions. Analytical Biochemistry. 373(1): 176-178. DOI:https://doi.org/10.1016/j.ab.2007.10.016. 
[13] Morrison, K. L. and Weiss, G. A. 2001. Combinatorial Alanine-scanning. Current Opinion in Chemical Biology. 5(3): $\quad 302-307 . \quad$ DOl:https://doi.org/10.1016/S1367$5931(00) 00206-4$.

[14] Biswas, A., Shukla, A., Vijayan, R. S. K., Jeyakanthan, J. and Sekar, K. 2017. Crystal Structures of an Archaeal Thymidylate Kinase from Sulfolobus Tokodaii Provide Insights into the Role of a Conserved Active Site Arginine Residue. Journal of Structural Biology. 197(3): 236-249. DOl:https://doi.org/10.1016/j.jsb.2016.12.001.

[15] Luo, L., Liu, Y.-Y., Gao, T., Wang, X., Chen, J., Wang, H., Liu, Y. and Cao, A. 2020. Characterization of the Specific Interactions between Nanoparticles and Proteins at Residue-resolution by Alanine Scanning Mutagenesis. ACS Applied Materials \& Interfaces. 12(31): 34514-34523.

[16] Yang, L.-K., Hou, Z.-S. and Tao, Y.-X. 2020. Biased Signaling in Naturally Occurring Mutations of $G$ Protein-coupled Receptors Associated with Diverse Human Diseases. Biochimica et Biophysica Acta (BBA)-Molecular Basis of Disease. 165973.

[17] Reimer, A., Maffenbeier, V., Dubey, M., Sentchilo, V., Tavares, D., Gil, M. H., Beggah, S. and van der Meer, J. R. 2017. Complete Alanine Scanning of the Escherichia Coli Rbsb Ribose Binding Protein Reveals Residues Important for Chemoreceptor Signaling and Periplasmic Abundance. Scientific Reports. 7(1): 1-11.

[18] Seenivasagan, R., Kasimani, R., Rajakumar, S., Kalidoss, R. and Ayyasamy, P. M. 2016. Comparative Modelling and Molecular Docking of Nitrate Reductase from Bacillus Weihenstephanensis (DS45). Journal of Taibah University for Science. 10(4): 621-630. DOl:https://doi.org/10.1016/j.jtusci.2016.02.006.

[19] Kumarasinghe, I. R. and Woster, P. M. 2018. Cyclic Peptide Inhibitors of Lysine-Specific Demethylase 1 with Improved Potency Identified by Alanine Scanning Mutagenesis. European Journal of Medicinal Chemistry. 148210-220. DOI:https://doi.org/10.1002/prot.23165.

[20] Hu, Y., Hua, Q., Sun, G., Shi, K., Zhang, H., Zhao, K., Jia, S., Dai, Y. and Wu, Q. 2018. The Catalytic Activity for Ginkgolic Acid Biodegradation, Homology Modeling and Molecular Dynamic Simulation of Salicylic Acid Decarboxylase. Computational Biology and Chemistry. 7582-90.

DOI:https://doi.org/10.1016/j.compbiolchem.2018.05.003.

[21] Pandurangan, A. P., Ochoa-Montaño, B., Ascher, D. B. and Blundell, T. L. 2017. SDM: A Server for Predicting Effects of Mutations on Protein Stability. Nucleic Acids Research. 45(W1): DOl:https://doi.org/10.1093/nar/gkx439.

W229-W235.

[22] Park, H., Ovchinnikov, S., Kim, D.E., DiMaio, F. and Baker, D. 2018. Protein Homology Model Refinement by Large-scale Energy Optimization. Proceedings of the National Academy of Sciences. 115(12): 3054-3059. DOl:https://doi.org/10.1093/nar/gkx439.

[23] Makarewicz, T. and Kaźmierkiewicz, R. 2013. Molecular Dynamics Simulation by GROMACS using GUI Plugin for PyMOL. J. Chem. Inf. Model. 1229-1234. DOI:https://doi.org/10.1021/ci400071x.

[24] Feig, M. 2017. Computational Protein Structure Refinement: Almost There, Yet Still So Far to Go. Wiley Interdisciplinary Reviews: Computational Molecular Science. 7(3): el307. DOI:https://doi.org/10.1002/wcms.1307.

[25] Hess, B., Kutzner, C., van der Spoel, D. and Lindahl, E. 2008. GROMACS 4: Algorithms for Highly Efficient, LoadBalanced, and Scalable Molecular Simulation. Journal of Chemical Theory and Computation. 4(3): 435-447. DOl:https://doi.org/10.1021/ct700301q.

[26] Colovos, C. and Yeates, T.O. 1993. Verification of Protein Structures: Patterns of Nonbonded Atomic Interactions. Protein Science. 2(9): 1511-1519. DOl:https://doi.org/10.1002/pro.5560020916.

[27] Anuar, N. F. S. K., Wahab, R. A., Huyop, F., Halim, K. B. A. and Hamid, A. A. A. 2019. In Silico Mutation on a Mutant
Lipase from Acinetobacter Haemolyticus Towards Enhancing Alkaline Stability. Journal of Biomolecular Structure and Dynamics. 1-15. DOI:https://doi.org/10.1080/07391 102.2019.1683074.

[28] Vedamurthy, G. V. Ahmad, H., Onteru, S. K. and Saxena, V. K. 2019. In Silico Homology Modelling and Prediction of Novel Epitopic Peptides from P24 Protein of Haemonchus Contortus. Gene. 703102-111. DOI:https://doi.org/10.1016/j.gene.2019.03.056.

[29] Elmayergi, B. H. 2000. Sketchy Details: Using the New ACD ChemSketch. Canadian Chemical News. 52(9): 9.

[30] Bahaman, A. H., Abdul Wahab, R., Hamid, A. A. A., Halim, K. B. A., Kaya, Y. and Edbeib, M. F. 2019. Substrate Docking and Molecular Dynamic Simulation for Prediction of Fungal Enzymes from Trichoderma Species-assisted Extraction of Nanocellulose from Oil Palm Leaves. Journal of Biomolecular Structure and Dynamics. 1-13. DOl:https://doi.org/10.1080/07391102.2019.1679667.

[31] Lemkul, J. 2018. From Proteins to Perturbed Hamiltonians: A Suite of Tutorials for the GROMACS-2018 Molecular Simulation Package [article v1. 0]. Living Journal of Computational Molecular Science. 1(1): 5068. DOl:https://doi.org/10.33011/livecoms.1.1.5068.

[32] Xiang, Z. 2006. Advances in Homology Protein Structure Modeling. Current Protein and Peptide Science. 7(3): 217227. DOl:https://doi.org/10.2174/138920306777452312.

[33] Edbeib, M. F., Wahab, R. A., Kaya, Y. and Huyop, F. 2017. In Silico Characterization of a Novel Dehalogenase (DehHX) from the Halophile Pseudomonas Halophila HX Isolated from Tuz Gölü Lake, Turkey: Insights into a Hypersaline-adapted Dehalogenase. Annals of Microbiology. 67(5): 371-382. DOl:https://doi.org/10.1007/s13213-017-1266-2.

[34] Kuriata, A., Gierut, A. M., Oleniecki, T., Ciemny, M. P., Kolinski, A., Kurcinski, M. and Kmiecik, S. 2018. CABS-flex 2.0: A Web Server for Fast Simulations of Flexibility of Protein Structures. Nucleic Acids Research. 46(W1): W338W343. DOl:https://doi.org/10.1093/nar/gky356.

[35] Yang, Y. 2016. Chapter 8 - Side Reactions on Hydroxyl and Carboxyl Groups in Peptide Synthesis. Y.B.T.-S.R. in P.S. Yang, ed. Academic Press. 203-216.

[36] Doering, J. A., Lee, S., Kristiansen, K., Evenseth, L., Barron, M. G., Sylte, I. and LaLone, C. A. 2018. In Silico Sitedirected Mutagenesis Informs Species-specific Predictions of Chemical Susceptibility Derived from the Sequence Alignment to Predict Across Species Susceptibility (SeqAPASS) Tool. Toxicological Sciences. 166(1): 131-145. DOI:https://doi.org/10.1093/toxsci/kfyl86.

[37] Worth, C. L., Preissner, R. and Blundell, T. L. 2011. SDM-A Server for Predicting Effects of Mutations on Protein Stability and Malfunction. Nucleic Acids Research. 39(suppl_2): DOl:https://doi.org/10.1093/nar/gkr363.

[38] Manas, N. H. A., Bakar, F. D. A. and Illias, R. M. 2016. Computational Docking, Molecular Dynamics Simulation and Subsite Structure Analysis of a Maltogenic Amylase from Bacillus Lehensis G1 Provide Insights into Substrate and Product Specificity. Journal of Molecular Graphics and Modelling. 671-13.

[39] Jeffrey, G. A. and Jeffrey, G. A. 1997. An Introduction To Hydrogen Bonding. Oxford university Press New York.

[40] Lee, H. S. and Zhang, Y. 2012. BSP-SLIM: A blind Low-Resolution Ligand-protein Docking Approach Using Predicted Protein Structures. Proteins: Structure, Function, and Bioinformatics. 80(1): 93-110 DOl:https://doi.org/10.1002/prot.23165.

[41] Kumar, R., Arora, J., Ruhil, S., Phougat, N., Chhillar, A. K. and Prasad, A. K. 2014. Synthesis and Antimicrobial Studies of Pyrimidine Pyrazole Heterocycles. Adv. Chem. 20141-12.

[42] Pandey, B., Grover, A. and Sharma, P. 2018. Molecular Dynamics Simulations Revealed Structural Differences among WRKY Domain-DNA Interaction in Barley (Hordeum vulgare). BMC Genomics. 19(1): 1-16.

[43] Cheng, L., Feng, T., Zhang, B., Zhu, X., Hamaker, B., Zhang, 
H. and Campanella, O. 2018. A Molecular Dynamics Simulation Study on the Conformational Stability of Amylose-linoleic Acid Complex in Water. Carbohydrate Polymers. 19656-65.

[44] Neitzel, J. J. 2010. Enzyme Catalysis: The Serine Proteases. Nature Education. 3(9): 21.
[45] Kovacic, F., Mandrysch, A., Poojari, C., Strodel, B. and Jaeger, K.-E. 2016. Structural Features Determining Thermal Adaptation of Esterases. Protein Engineering, Design and Selection. 29(2):

DOI:https://doi.org/10.1093/protein/gzv061.
65-76. 